\title{
PENINGKATAN PRESTASI BELAJAR PAI SISWA SD BERSIH ITU SEHAT MELALUI MULTIMEDIA INTERAKTIF
}

\author{
FATIMAH \\ UPT SDN 1 Benteng, Kecamatan Baranti, Sidrap \\ fatima300776@gmail.com
}

\begin{abstract}
ABSTRAK
Penelitian ini bertujuan untuk mengatasi masalah yang ada dalam pembelajran Tema Bersih itu sehat dengan menggunakan multimedia interaktif di kelas IV SDN 1 Benteng Kecamatan Baranti Kabupaten Sidenreng Rappang. Penggunaan multimedia interaktif pada pembelajaran bersih itu sehat dapat mempengaruhi peningkatan prestasi belajar peserta didik, dimana pada pra observasi sebelum menggunakan multimedia interaktif prestasi belajar peserta didik hanya sekitar $70 \%$ ketuntasan belajarnya dan nilai ratarata kelas hanya mencapai nilai 70 masih dibawah nilai KKM yaitu 75. Sedangkan setelah menggunakan multimedia interaktif dalam pembelajaran, prestasi belajar peserta didik meningkat pada siklus I nilai rata-rata kelas sudah bertambah menjadi 75 dan pada siklus II nilai rata-rata Kelas menjadi 85, sedangkan untuk ketuntasan klasikalnya pada siklus I persentae p mencapai $75 \%$ dan pada siklus II meningkat lagi pmenjadi 90\%, dimana indicator keberhasilan yaitu 85\%. Ini artinya bahwa dengan menggunakan multimedia interaktif sebagai salah satu alat penyampai pesan dapat mempengaruhi prestasi belajar peserta didik.
\end{abstract}

Kata Kunci: Prestasi Belajar, Multimedia Interaktif

\section{PENDAHULUAN}

Pandemi virus corona berimbas pada dunia pendidikan. Pembelajaran yang dulunya dilakasanakan secara tatap muka, memaksa kita untuk melaksanakan pembelajaran jarak jauh (PJJ). Pembelajaran ini memanfaatkan hp dan internet dalam proses penyampaian materi pembelajaran. Berbagai tantangan yang dihadapi dan ini sangat membutuhkan kerjasama semua pihak mulai dari pemerintah, guru, orangtua, masyarakat dan peserta didik itu sendiri.

Berkaitan dengan pembelajaran dalam kelas, yang tahun ini pelaksanaannya agak berbeda dengan tahun-tahun sebelumnya. Sebagai seorang pendidik kami berusaha semaksimal mungkin dengan situsai yang serba online, juga harus jeli dalam menyajikan meteri ajar, misalnya pada pelaksanaan pembelajaran tema Bersih itu Sehat. Materi ini membahas tentang pengenalan arti bersih, suci, najis dan cara mempraktikkan tatacara bersuci. Adapun judul penelitian ini adalah Peningkatan Prestasi Belajar PAI Bersih itu Sehat Kelas IV SDN 1 Benteng Baranti Melalui Multimedia Interaktif.

Materi ini sengaja peneliti angkat sebagai akar masalah yang ditemukan dalam kelas. Ketika proses pembelajaran secara online berlangsung peserta didik sepertinya kurang aktif dalam pembelajaran, lambat mengumpulkan tugas sehingga pembelajaran tidak maksimal dan tentunya akan mempengaruhi hasil belajar peserta didik. 
Keberhasilan suatu pembelajaran sangat ditentukan oleh seberapa besar anak yang aktif dalam mengikuti pembelajaran, terbangunnya energi positif kepada peserta didik sehingga setelah proses pembelajaran selesai ada perubahan pada pola tingkah laku, pemahaman materi serta penyerapan ilmu yang akan mempengaruhi semangatnya dalam belajar sehingga termotivasi terus untuk mengetahui pelajaran yang akan disampaikan.

Karena peserta didik merupakan pusat pembelajaran harapannya ketika materi pelajaran yang disampaikan bisa diperhatikan dengan baik, kemudian peserta didik dapat termotivasi dan akan berusaha untuk mengerjakannya yang akhirnya secara spontan dapat mengikuti dan mempraktikkannya.

Olehnya itu seorang pendidik berusaha dengan sungguh-sungguh sehingga materi yang akan diajarkan dalam kelas disajikan dengan menarik dan dapat memotivasi peserta didik dalam belajar. Apalagi pada masa pandemi ini, proses pembelajaran yang sebelumnya secara langsung atau tatap muka dalam kelas sekarang dilaksanakan secara tidak langsung melalui pembelajaran daring. Pembelajaran jarak jauh ini merupakan pembelajaran baru sehingga butuh waktu dan tenaga untuk mengaplikasikan materi yang akan diajarkan supaya peserta didik tetap semangat belajar walaupun situasi ruang belajarnya didunia maya.

Kumparan.com (2020). Mendikbud Nadiem Makarim mengatakan, hanya sekolah yang berada di zona hijau yang dapat melaksanakan prosese pebelajaran dengan tatap muka yang tentunya tetap memberlakukan protokol kesehatan. Dengan demikian permasalahan yang dihadapi pendidik dalam penyampaian metari melalui pembelajaran jarak jauh tetap berusah memanfaatkan teknologi dan berusaha menggunankan metode yang bisa dipakai melalui kelas maya, misalnya penggunaan multimedia interaktif.

Situmorang (2014) mengatakan, hasil pembelajaran peserta didik dengan menggunakan multimedia interaktif berpengaruh positif sehingga peserta didik lebih termotivasi dalam belajarnya dibandingkan hanya membaca dari buku pelajaran. Olehnya itu materi yang disampaikan diusahakan sejalan dengan situasi pendemi yang secara tidak langsung tatap muka.

Septian (2015) mengatakan perbandingan hasil belajar antara peserta didik yang menggunakan media interaktif dengan yang tidak mencapai 80,77\%. Ini menggambarkan bahwa dengan adanya media sebagai salah satu sarana dalam penyampaian materi pembelajaran akan snagat mempengaruhi hasil belajar peserta didik. Sedangkan Leow \& Neo (2014) mengatakan dengan menggunakan media inetarktif dalam pembelajaran prestasi belajar peserta didik lebih meningkat dan memberikan dampak positif terhadap hasil belajarnya. Sehingga penggunaan media dalam pembelajaran

Dari beberapa pendapat tersebut kami berharap dengan penggunaan multimedia interaktif dapat mempengaruhi hasil belajar peserta didik. Adanya pembelajaran yang berpusat pada peserta didik akan memberikan ruang gerak untuk mengeksplor dan melatih kemampuan peserta didik itu sendiri sehingga peserta didik termotivasi dan semangat dalam belajar.

Dari hasil penelitian pra observasi terhadap proses pembelajaran PAI Bersih itu Sehat Kelas IV SDN 1 Benteng Baranti, diketahui bahwa: 
1. Metode pembelajaran masih kurang mengaktifkan peserta didik dan masih perlu adanya pengembangan metode yang lebih memotivasi peserta didik sehingga prestasi belajarnya dapat meningkat.

2. Dari hasil pengamatan rata-rata nilai peserta didik dibawah KKM yaitu 75 dari 16 peserta didik, hanya 5 orang yang tuntas (31\%) sedangkan 11 orang tidak tuntas (69\%).

3. Pendidik (peneliti) masih mengalami hambatan dalam mengaktifkan peserta didik dalam bentuk pemahaman peserta didik terhadap materi yang disampaikan.

Olehnya itu, peneliti berusaha mencari media yang dapat memotivasi peserta didiknya agar aktif mengikuti pembelajaran. Media yang dipakai dalam pembelajaran PAI tema bersih itu sehat multimedia interaktif dengan tujuan ketika materi yang disampaikan peserta didik setelah melihat atau memerhatikannya dapat termotivasi untuk melakukan kemudian tergerak untuk memperaktikkannya secara spontan. Untuk berhasilnya, seorang pendidik dalam pembelajaran harus memperhatikan kemampuan peserta didknya, sehingga ketika ada yang kurang aktif bisa langsung mengarahkannya dan membimbingnya dan mampu menumbuhkan semangat serta rasa percaya diri pada peserta didiknya.

Ruang lingkup penelitian meliputi kongnitif ( $\mathrm{C} 1$ pengetahuan, $\mathrm{C} 2$ pemahaman, C3 penerapan, C4 analisis), afektif (keaktifan dan kehadiran peserta didik di grup kelas WhatsApp) dan psikomotorik (keterampilan dan kesungguhan dalam praktikkan materi bersih itu sehat).

Dimasa pandemi ini keinginan anank-anak tentang multimedia sangat besar, sehingga melalui penelitian ini kami akan menggunkan metode yang berpusat pada peserta didik dengan melibatkan teknologi multimedia interkatif yang nantinya setelah peserta didik melihat dan menyaksikan video yang dikirm melalui grup kelas WhatsApp peserta didik langsung termotivasi dan ingin melakukan apa yang dilihatnya.

Adapun alasan peneliti menggunakan multimedia interaktif dalam peningkatan hasil belajar diharapkan peserta didik tetap aktif dan bersemangat dalam belajar dan selalu ingin mencoba hal yang baru sehinnga tidak menimbulkan kejenuhan dalam belajar karena hanya terfokus pada metode ceramah atau metode tidak bervariasi.

Dari uraian diatas, peneliti tertarik untuk melakukan penelitian dengan judul "Peningkatan Prestasi Belajar PAI Bersih itu Sehat Kelas IV SDN 1 Benteng Baranti melalui Multimedia Interaktif.

\section{METODE PENELITIAN}

Penelitian ini menggunakan metode penelitian tindakan kelas sebagai solusi masalah yang ditemukan dalam kelas. Dalam penelitian ini, pendidik dapat menganalisis apa yang telah dilakukan dalam kelas untuk memperbaiki prestasi belajar.

Aqib (2006) mengatakan bahwa penelitian yang dilakukan dalam kelas tetap mengikuti petunjuk dasar yang diberlakukan dalam sebuah penelitian kelas. Arikunto (2009:3) mengatakan penelitian ini didasarkan atas masalah yang muncul didalam

kelas yang kemudian akan diberikan tindakan dan mencari solusinya sehingga masalah yang yang ditemukan dapat teratasi. Berdasrkan hal tersebut maka yang akan diteliti adalah peningkatan prestasi belajar PAI Kelas IV UPT SDN 1 Benteng Baranti melalui multimedia interaktif. 
Dalam penelitian ini ada empat tahapan yang akan dilalui yaitu perencanaan, pelaksanaan, pengamatan dan refleksi. Dari tahapan tersebut peneliti hanya melaksanakannya dalam dua siklus. Metode Pengumpulan Data

a. Data yang akan dikumpulkan selama pelaksanaan PTK yaitu data kuantitatif berupa nilai hasil belajar peserta didik dan data kualitatif berupa observasi selama pembelajaran berlangsung.

b. Instrumen yang akan digunakan dalam mengumpulkan data yaitu tes, observasi dan dokumentasi

\section{Metode Analisis Data}

Penelitian ini menggunakan dua jenis data yakni data yang berupa kuatitatif dann data kulaitatif. Data kuantitatif yang dimaksud adalah hasil tugas trtulis yang diberikan dalam video akhir pembelajaran dan tingkat keaktifan atau persentase peserta didik. Kemudian datanya dianalisa dengan menghitung rata-rata atau persentasi prestasi belajar peserta didik. Sedangkan data kualitatif berupa hasil survey selama pembelajaran berlangsung

\section{Indikator Keberhasilan}

Indikator keberhasilan dari penelitian ini dapat dilihat dari peningkatan prestasi belajar peserta didik pada setiap siklus meningkat.

Mulyasa (2009) mengatakan bahwa standar ketuntasan pembelajaran secara kelompok mencapai $85 \%$ dan secara peorangan memenuhi ketuntasan minimal yaitu $75 \%$.

\section{HASIL DAN PEMBAHASAN}

Penelitian ini dilaksanakan di Kelas IV UPTD SDN 1 Benteng Kecamatan Baranti Kabupaten Sidenreng Rappang Provinsi Sulawesi Selatan. Pada awal penelitian metode yang digunakan adalah ceramah.

Dari hasil observasi awal metode yang digunakan masih memakai metode yang konvensional, sehingga pendidik lebih dominan dalam pembelajaran dibandingkan peserta didik. Waktu peserta didik dalam menyampaikan pendapatnya masih kurang dan tidak tereksplor.

Siklus I

Dalam menyampaikan materi ajar melalui grup kelas whatsApp pendidik mengirim video tentang memahami tata cara bersuci dari hadas kecil dan hadas besar sesuai ketentuan syariat Islam. Pendidik (peneliti) meminta peserta didik untuk menyimak video dengan baik sampai selesai, Karena diakhir video akan ada tugas berupa pertanyaan tentang memahami tata cara bersuci dari hadas kecil dan hadas besar sesuai ketentuan syariat Islam. Setelah menonton video, pendidik menyampaikan sebelum mengerjakan tugas peserta didik diharapkan mengajukan pertanyaan jika ada yang belum dipahami.

Diakhir Siklus I, pendidik melakukan tes dengan tujuan sejauh mana peserta didik memahami materi yang telah disampaikan. Adapun prestasi belajar peserta didik di Siklus I dapat dilihat pada table berikut: 
Tabel. 1 Prestasi Belajar Peserta Didik Siklus I

\begin{tabular}{|c|l|c|}
\hline No & \multicolumn{1}{|c|}{ Keterangan } & Skor \\
\hline 1 & Nilai Terendah & 65 \\
\hline 2 & Nilai Tertinggi & 85 \\
\hline 3 & Nilai Rata-rata Kelas & 73 \\
\hline 4 & Jumlah Peserta didik Yang Belum Tuntas & 7 \\
\hline 5 & Jumlah Peserta Didik yang Tuntas & 9 \\
\hline 6 & Persentase Ketuntasan Klasikal & $75 \%$ \\
\hline
\end{tabular}

Dari hasil Siklus I, peserta didik masih ada 7 orang yang belum tuntas yaitu belum mencapai nilai 75 sedangkan 9 orang yang sudah tuntas dengan rata-rata ketuntasan minimal adalah $75 \%$.

Dengan penggambaran hasil Siklus I dapat disimpulkan bahwa prestasi belajar peserta didik sudah mengalami peningkatan dimana rata-rata awal pengamatan ke Siklus I dari nilai $70 \%$ menjadi $75 \%$. Meskipun dari rata-rata kelas prestasi belajarnya ada peningkatan akan tetapi indikator ketuntasan klasikalnya belum tercapai yaitu masih 75\% sehingga masih berlanjut ke Siklus II.

Selain peserta didik pengamatan tentang aktivitas pendidik juga sangat mendukung dalam pelaksanaan Siklus I. Dari table berikut dapat diperhatikan :

Tabel.2 Aktivitas Peserta Didik Siklus I

\begin{tabular}{|l|l|c|}
\hline No & \multicolumn{1}{|c|}{ Aktivitas Peserta Didik } & Skor \\
\hline 1 & Peserta didik aktif dalam pembelajaran & 4 \\
\hline 2 & Kemampuan peserta didik dalam menyelesaikan tugas & 3 \\
\hline 3 & Ketepatan waktu mengirim tugas & 2 \\
\hline 4 & Peserta didik menjawab tugas & 3 \\
\hline 5 & Perhatian peserta didik terhadap materi pelajaran & 3 \\
\hline 6 & Jumlah Skor & 15 \\
\hline 7 & Persentase & 75 \\
\hline
\end{tabular}

Dari aktivitas peserta didik di Sikluus I dapat disimpulkan bahwa dengan penggunaan video dalam pembelajaran prestasi belajar peserta didik mengalami 
peningkatan dimanan persentasenya mencapai $75 \%$ dengan kategori baik. Meskipun demikian belum mencapai indikator aktivitas peserta didik yaitu $80 \%$. Dari deskripsi tersebut, peneliti perlu melanjutkan ke siklus II sebagai upaya perbaikan prestasi belajar dapat memenuhi kriteria yang telah ditentukan.

Untuk hasil aktivitas pendidik dapat diperhatika table berikut:

Tabel.3 Aktivitas Pendidik Siklus I

\begin{tabular}{|c|l|c|}
\hline No & \multicolumn{1}{|c|}{ Aktivitas Pendidik } & Skor \\
\hline 1 & Penggunaan Media Pembelajaran & 3 \\
\hline 2 & Menbangun Komunikasi Dua Arah & 3 \\
\hline 3 & Mengorganisasi Peserta Didik & 3 \\
\hline 4 & Membimbing Peserta Didik & 3 \\
\hline 5 & Menjawab Pertanyaan Prserta Didik & 3 \\
\hline 6 & Memberikan Motivasi Pesrta Didik & 18 \\
\hline 6 & Jumlah & 3 \\
\hline 7 & Rata-rata & \\
\hline
\end{tabular}

Kesimpulan dari siklus I yaitu Prestasi belajar peserta didik sudah mengalami peningkatan dibuktikan dengan nilai klasikal pada awal pengamatan dari $45 \%$ menjadi $75 \%$ tetapi indikator keberhasilan belum mencapai yaitu $85 \%$. Pada aktivitas peserta didik pada siklus I juga suda mengalami peningkatan yaitu $75 \%$ akan tetapi belum mencapai kriteria yaitu $80 \%$. Pendidik dalal pengelolaan kelas juga sudah masuk dalam kategori baik akan tetapi masih perlu memaksimalkan kemampuannya dalam tercapainya indicator keberhasil agar prestasi belajar peserta didik meningkat.

\section{Siklus II}

Pelaksanaaan siklus II kurang lebih sama dengan siklus ihanya saja pemberian motivasi kepada peserta didik lebih ditingkatkan disbanding siklus sebelumnya.Pada akhir siklus II Prestasi belajar peserta didik dapat dilihat dari tabel berikut: 
Tabel.4 Prestasi Belajar Peserta Didik Siklus II

\begin{tabular}{|c|l|c|}
\hline No & \multicolumn{1}{|c|}{ Keterangan } & Skor \\
\hline 1 & Nilai Terendah & 75 \\
\hline 2 & Nilai Tertinggi & 95 \\
\hline 3 & Nilai Rata-rata Kelas & 85 \\
\hline 4 & Jumlah Peserta didik Yang Belum Tuntas & 0 \\
\hline 5 & Jumlah Peserta Didik yang Tuntas & 16 \\
\hline 6 & Persentase Ketuntasan Klasikal & $100 \%$ \\
\hline
\end{tabular}

Dari tabel tersebut dapat dilihata prestasi belajar peserta didik mengalami peningkatan dimana pada siklus I nilai ketuntasan $75 \%$ kemudin meningkat disiklus II dengan nilai $100 \%$. Ini berarti indicator ketuntasan klasikal melebihi indicator keberhasilan yaitu $85 \%$. Ini berarti prestasi belajar pada siklus II sudah tuntas.

Tabel.5 Aktivitas Peserta Didik Siklus II

\begin{tabular}{|l|l|c|}
\hline No & \multicolumn{1}{|c|}{ Aktivitas Peserta Didik } & Skor \\
\hline 1 & Peserta didik aktif dalam pembelajaran & 4 \\
\hline 2 & Kemampuan peserta didik dalam menyelesaikan tugas & 3 \\
\hline 3 & Ketepatan waktu mengirim tugas & 3 \\
\hline 4 & Peserta didik menjawab tugas & 4 \\
\hline 5 & Perhatian peserta didik terhadap materi pelajaran & 4 \\
\hline 6 & Jumlah Skor & 18 \\
\hline 7 & Persentase & $90 \%$ \\
\hline
\end{tabular}

Tabel tersebut menggambarkan adanya peningkatan aktivitas belajar peserta didik dari $75 \%$ menjadi $90 \%$ pada siklus II. Ini mengisyaratkan aktivitas peserta didik sudah diatas batas minimal keberhasilan yaitu $80 \%$. 
Tabel.6 Aktivitas Pendidik Siklus II

\begin{tabular}{|c|l|c|}
\hline No & \multicolumn{1}{|c|}{ Aktivitas Pendidik } & Skor \\
\hline 1 & Penggunaan Media Pembelajaran & 3 \\
\hline 2 & Menbangun Komunikasi Dua Arah & 3 \\
\hline 3 & Mengorganisasi Peserta Didik & 4 \\
\hline 4 & Membimbing Peserta Didik & 4 \\
\hline 5 & Menjawab Pertanyaan Peserta Didik & 4 \\
\hline 6 & Memberikan Motivasi Pesrta Didik & 4 \\
\hline 7 & Jumlah & 18 \\
\hline 8 & Rata-rata & 4 \\
\hline
\end{tabular}

Tabel.7 Peningkatan Prestasi Belajar Peserta Didik Ditiap Siklus

\begin{tabular}{|c|l|c|c|}
\hline No & Siklus & Nilai Rata-rata & Persentase ketuntasan \\
\hline 1 & Pra & 71 & 71 \\
\hline 2 & Siklus 1 & 75 & 75 \\
\hline 3 & Siklus II & 85 & 100 \\
\hline
\end{tabular}

Tabel.8 Peningkatan Aktivitas Peserta Didik Ditiap Siklus

\begin{tabular}{|c|l|c|c|}
\hline No & Siklus & Nilai Rata-rata & Persentase ketuntasan \\
\hline 1 & Pra & 2 & 45 \\
\hline 2 & Siklus 1 & 3 & 75 \\
\hline 3 & Siklus II & 4 & 90 \\
\hline
\end{tabular}

Dari analisa data pada tiap siklus dapat dilihat adanya peningkatan prestasi belajar peserta didik meningkat. Ini artinya dengan penggunaan multimaedia interaktif dapat dipakai sebagai salah satu salah satu sarana penyampai imformasi dalam pembelajaran. Adapun keuntungan dengan menggunakan multimedia interaktif dalam pembelajaran yaitu dapat memotivasi peserta didik dalam belajar, memberikan 
pengalaman baru kepada peserta didik, efektif dan efisien dalam menyampaikan pesan kepada peserta didik.

\section{KESIMPULAN}

Berdasarkan hasil penelitian tentang peningkatan prestasi belajar PAI siswa Kelas IV bersih itu sehat melalui multimedia interaktif di UPT SDN 1 Benteng Semeseter Ganjil Tahun Ajaran 2020/2021 adalah dapat meningkatkan prestasi belajar peserta didik dan dapat membantu pendidik dalam menyampaikan pesan pembelajaran. Hal ini dapat dilihat pada siklis I nilai rata-rata kelas peserta didik yaitu 75 sedangkan pada siklus II dengan nilai 85 dan untuk peningkatan ketuntasan aktivitas belajar pada siklus I dengan nilai $75 \%$ dan siklus II nialaninya $90 \%$.

Adapun saran dalam penelitian ini yaitu : Bagi peserta didik, melalui hasil penelitian ini diharapkan peserta didik lebih termotivasi, lebih aktif, menambah pengalaman baru dan tidak jenuh sehingga dapat meningkatkan prestasi belajarnya. Bagi pendidik, diharapkan dari penelitian ini dapat dijadikan salah satu refrensi dalam mengajar sehingga bisa berinovasi dan tidak monoton ketika mengajar. Bagi sekolah, diharapkan hasil penelitian ini dapat memberikakan kontribusi kepada pendidik, kepala sekolah serta pihak yang terkait sehingga memperoleh pengalaman baru dan danpat menerapkan pendekatan dalam pembelajaran.

\section{DAFTAR PUSTAKA}

Anwar dan Ahmad, Arsyad. 2007. Pendidikan Anak Dini Usia. Bandung: Alfabeta. Arsyad, A. (2003). Media Pembelajaran. Jakarta: PT Raja Grafindo Persada Elihami, E., \& Syahid, A. (2018). Penerapan Pembelajaran Pendidikan Agama Islam Dalam Membentuk Karakter Pribadi Yang Islami. Edumaspul-Jurnal Pendidikan, 2(1), 79-96.

Leow, F.-T., \& Neo, M. (2014). Interactive Multimedia Learning: Innovating Classroom Education in a Malaysian University. Turkish Online Journal of Educational Technology-TOJET, 13(2), 99-110.

Mulyasa. (2003). Menjadi guru profesional. Bandung: PT Remaja Rosda Karya.

Sanjaya, W. (2010). Strategi Pembelajaran Berorientasi Standar Proses Pendidikan. Jakarta: Kencana.

Septian, D. (2015). Pengembangan Multimedia Interaktif Berbasis Learning Cycle pada Materi Alat Optik Menggunakan Flash dalam Pembelajaran IPA SMP Kelas VIII. UNS (Sebelas Maret University). Diambil dari https://goo.gl/HjEsJx

Slameto. (2010). Belajar Dan Faktor-Faktor Yang Mempengaruhi Belajar. Jakarta: Rineka Cipta.

Zaenal, A. (2012). Tesis. Pengembangan Media Video Pembelajaran IPA tentang Kemagnetan pada kelas IX SMPN 1 Mojowarno Jombang. 